\title{
Phylogeny of the genus Stephomyia Tavares, 1916 (Diptera: Cecidomyiidae)
}

\author{
V. C. Maia ${ }^{a *}$ and L. S. Barbosa ${ }^{a}$ \\ ${ }^{a}$ Museu Nacional, Quinta da Boa Vista, São Cristóvão, CEP 20940-040, Rio de Janeiro, RJ, Brazil \\ *e-mail: maiavcid@acd.ufrj.br
}

Received: April 11, 2016 - Accepted: August 30, 2016 - Distributed: February 28, 2018

(With 57 figures)

\begin{abstract}
Stephomyia Tavares, 1916 comprises seven species, all Neotropical: S. clavata (Tavares, 1920); S. epeugeniae Gagné, 1994; S. espiralis Maia, 1993; S. mina Maia, 1993; S. rotundifoliorum Maia, 1993; S. tetralobae Maia, 1993; and S. eugeniae (Felt, 1913). In the present study, a cladistic analysis based upon adult, pupa, larva and gall morphological characters as well as host plant data is carried out in order to discuss the monophyly of the genus and the relationships among the known species. The Stephomyia monophyly was supported by eight synapomorphies: five homoplastic characters and three non-homoplastic characters. Analyzes showed S. clavata with great instability within the genus, probably due to lack of larva, pupa and female data, so $S$. clavata was deactivated in analyze. The topology found was $(S$. mina $((S$. eugeniae $+S$. epeugeniae) $(S$. tetralobae $(S$. rotundifoliorum + S. espiralis $))))$.
\end{abstract}

Keywords: galling species, cladistics, systematic, taxonomy.

\section{Filogenia do gênero Stephomyia Tavares, 1916 (Diptera: Cecidomyiidae)}

\section{Resumo}

Stephomyia Tavares, 1916 compreende sete espécies, todas neotropicais: S. clavata (Tavares, 1920); S. epeugeniae Gagné, 1994; S. espiralis Maia, 1993; S. mina Maia, 1993; S. rotundifoliorum Maia, 1993; S. tetralobae Maia, 1993 e S. eugeniae (Felt, 1913). Neste estudo, uma análise cladística baseada em caracteres morfológicos dos adultos, pupa, larva e galha, bem como na informação das plantas hospedeiras é realizada e a monofilia do gênero e as relações entre as espécies conhecidas são discutidas. A monofilia de Stephomyia foi suportada por oito sinapomorfias: cinco caracteres homoplásticos e três não homoplásticos. Análises mostraram uma grande instabilidade de $S$. clavata dentro do gênero, provavelmente devido à falta de informações sobre a larva, a pupa e a fêmea, o que resultou em desativação na análise. A topologia encontrada foi $(S$. mina $((S$. eugeniae + S. epeugeniae $)(S$. tetralobae $(S$. rotundifoliorum + S. espiralis $))))$.

Keywords: espécies galhadoras, cladística, sistemática, taxonomia.

\section{Introduction}

Stephomyia Tavares, 1916 (Diptera, Cecidomyiidae) is a Neotropical genus with seven described species: S. clavata (Tavares, 1920); S. epeugeniae Gagné, 1994; S. espiralis Maia, 1993a; S. eugeniae (Felt, 1913); S. mina Maia, 1993a; S. rotundifoliorum Maia, 1993a; and S. tetralobae Maia, 1993a. S. clavata is only known as male; $S$. epeugeniae as male and female; $S$. espiralis as female and pupa; S. eugeniae as male, female and pupa; $S$. mina, S. rotundifoliorum and $S$. tetralobae as male, female, pupa and larva. All galls are described.

Six species are from South America, and one, S. eugeniae, from North America (USA, Florida) (Figure 1). All are gallers on Myrtaceae, being five associated with Eugenia L. and only one with Neomitranthes D. Legrand, namely S. mina. The host plant genus of Stephomyia clavata is not determined (Gagné and Jaschhof, 2014). In the Table 1, the host plant of each galling species is presented.
Stephomyia belongs to the tribe Asphondyliini, distinctive by female seventh sternite that is much longer than the preceding ones; the strongly, sclerotized, wide, and laterally notched female eighth tergite, the ventrally lengthened gonocoxites; and the dorsally, apically disposed, short, flat, and broad gonostyli (Gagné, 1994). The tribe is divided into two subtribes: Asphondyliina with 375 species in 19 genera and Schizomyiina with 164 species in 26 genera, including Stephomyia (Gagné and Jaschhof, 2014). Both taxa are well defined: the former presents an apical projection on the first tarsomere of each leg; a large, bilobed structure at the posterior end of the female eighth tergite; no parameres (except in Zalepidota Rübsaamen, 1907); and the denticles of the gonostyli at least partly fused into a solid tooth or teeth. The latter lacks the apical projection on the first tarsomere of each leg, as well as the bilobed structure at the posterior end of the female eighth 
tergite; male terminalia have parameres; and the denticles of the gonostyli are not fused.

Some genera of Asphondyliini were covered partially by Tokuda et al. $(2005,2008)$ and Dorchin et al. (2015). A single work deals with the fauna of the Neotropical Region, Möhn (1962), who analyzed the relations among the Neotropical genera, but without using cladistic methods. At this time, Stephomyia comprises a single species. Since then, other six species were added, but the

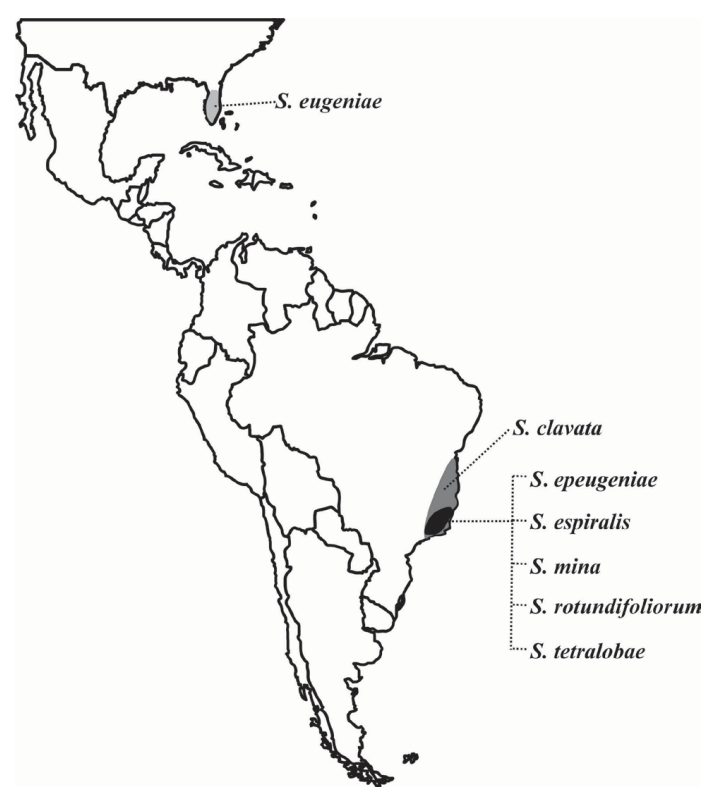

Figure 1. Map of distribution of Stephomyia Tavares, 1916 (Diptera, Cecidomyiidae). phylogenetic relationships among them are still unknown. The purposes of this study are: 1) to test the monophyly of the genus Stephomyia and, 2) to propose phylogenetic relationships among the species.

\section{Material and Methods}

Twenty-three species are included in this study. The in-group consists of all described species of Stephomyia: S. clavata (Tavares, 1920); S. epeugeniae Gagné, 1994; S. espiralis Maia, 1993; S. eugeniae (Felt), 1913; S. mina Maia, 1993; S. rotundifoliorum Maia, 1993 and S. tetralobae Maia, 1993. The type material of $S$. espiralis, $S$. mina, $S$. rotundifoliorum, and $S$. tetralobae were examined, as well as the male of $S$. tetralobae, described by Maia (2002), all deposited in the Cecidomyiidae collection of Museu Nacional/Universidade Federal do Rio de Janeiro (MNRJ). Data on S. clavata, S. epeugeniae and S. eugeniae were obtained from literature (Felt, 1913; Gagné, 1994; Möhn, 1962; Tavares, 1920). The lack of data on S. clavata generated great instability of this taxon in the previous analysis, which led to its deactivation (Table 2).

The out-group consists of 16 species, representing two supertribes of Cecidomyiinae: Cecidomyiidi (where Stephomyia is included) and Lasiopteridi (the sister-group of Cecidomyiidi) (Gagné, 1994). The former is divided into 11 tribes and the latter into 8. Among Cecidomyiidi, we included species from three tribes: Cecidomyiini (Parkiamyia paraensis Maia, 2006 (in Maia and Fernandes, 2006) and Contarinia gemmae Maia, 2002 (in Madeira et al., 2002); Clinodiplosini (Clinodiplosis melissae Maia, 1993b and Iatrophobia braziliensis Rübsaamen, 1916); and Asphondyliini (Asphondyliina: Asphondylia fructicola Maia, 2009 (in Maia et al., 2009a); Bruggmanniella doliocarpi Maia, 2010 (in Maia et al., 2010), and Parazalepidota clusiae

Table 1. List of Stephomyia Tavares, 1916 (Diptera, Cecidomyiidae) species and respectively host plants.

\begin{tabular}{ll}
\hline \multicolumn{1}{c}{ Galling species } & \multicolumn{1}{c}{ Host plant } \\
\hline S. clavata (Tavares), 1920 & Myrtaceae (undetermined) \\
S. epeugeniae Gagné, 1994 & Eugenia sp. \\
S. espiralis Maia, 1994 & Eugenia copacabanensis Kiaersk \\
S. eugeniae (Felt), 1913 & Eugenia buxifolia Lam. \\
S. mina Maia, 1994 & Neomitranthes obscura (DC.) N. Silveira \\
S. rotundifoliorum Maia, 1994 & Eugenia astringens Cambess. (=Eugenia rotundifolia Casar) \\
S. tetralobae Maia, 1994 & Eugenia copacabanensis Kiaersk \\
\hline
\end{tabular}

Table 2. List of Stephomyia Tavares, 1916 (Diptera, Cecidomyiidae) species and described stages and sexes.

\begin{tabular}{lcccc}
\hline \multicolumn{1}{c}{ Galling species } & \multicolumn{4}{c}{ Described stages } \\
\cline { 2 - 4 } & male & female & pupa & larva \\
\hline S. clavata (Tavares), 1920 & $\mathrm{x}$ & & & \\
S. epengeniae Gagné, 1994 & $\mathrm{x}$ & $\mathrm{x}$ & $\mathrm{x}$ & \\
S. espiralis Maia, 1994 & & $\mathrm{x}$ & $\mathrm{x}$ & $\mathrm{x}$ \\
S. eugeniae (Felt), 1913 & $\mathrm{x}$ & $\mathrm{x}$ & $\mathrm{x}$ & $\mathrm{x}$ \\
S. mina Maia, 1994 & $\mathrm{x}$ & $\mathrm{x}$ & $\mathrm{x}$ & $\mathrm{x}$ \\
S. rotundifoliorum Maia, 1994 & $\mathrm{x}$ & $\mathrm{x}$ & $\mathrm{x}$ & \\
S. tetralobae Maia, 1994 & $\mathrm{x}$ & $\mathrm{x}$ & & \\
\hline
\end{tabular}


Maia, 2001a, Schizomyiina: Bruggmannia elongata Maia and Couri, 1993; Burseramyia braziliensis Maia and Fonseca, 2012, and Schizomyia spherica Maia and Oliveira, 2007. Among Lasiopteridi, we included species from Alycaulini (Baccharomyia magna Maia, 2012 (in Maia and Carneiro, 2012) and Neolasioptera ramicola Maia, 2009) (in Maia et al., 2009b); Dasineurini (Arcivena kielmeyerae Gagné, 1984 and Dasineura gigantea Angelo and Maia, 1999), Trotterini (Trotteria quadridentata Maia, 2001b) and Myrciariamyia fernandesis Maia, 2004 (unplaced to tribe). All out-group were studied based on the type-material, which is deposited in the Cecidomyiidae collection of MNRJ, except by A. kielmeyerae (data obtained from literature) and Iatrophobia braziliensis (data based on specimens of MNRJ).

\subsection{Cladistic analysis}

The Matrix was constituted of 23 terminals; 39 morphological characters, coded as non-additive, from three life stages, galls and host plants were included in the analysis: five from adult, 13 from male, seven from female, six from pupa, five from the third-instar larvae and three from gall. Of the 39 characters, 25 were binary and 14 multistate. Missing data are represented by question marks (?) and inapplicable characters by dash (-) (Table 3 ). We followed the terminology of McAlpine (1981) for adults and Gagné (1994) for immature phases.

Cladistic analysis was carried out using parsimony criteria using TNT ver.1.0 (Goloboff et al., 2005). Tree searches were conducted using the "New technologies" (with ratchet (100 interactions), tree drifting (100 cycles), tree fusing (100 rounds) and collapsing trees) and posteriorly Traditional Search (with "Wagner trees" random seed " 0 " 10,000 replications and 100,000 trees to save per replication). Absolute Bremer supports (Bremer, 1994) were calculated, using TNT ver.1.0, saving up to 30 steps longer suboptimal trees obtained with TBR. Cladograms were edited with WinClada (NIXON 1999).

\subsection{Characters description}

\subsubsection{Adult characters}

0 . Number of antennal flagellomeres: $12(0)$; more than 12 (1) 04 (3)

1. Number of palpi segments: 01 (0); 02 (1); 03 (2);

2. Apical projection on the first tarsomere of each leg: absent (0); present (1) (Figure 2)

3. Teeth of tarsal claws: absent (0) (Figure 3; present (1) (Figure 4)

4. Relative length of $\mathrm{R}_{5}$ : long, reaching $\mathrm{C}$ near apex (Figure 5); short, reaching $\mathrm{C}$ appreciably before apex (1) (Figure 6)

\subsubsection{Male characters}

5. Shape of male antennal flagellomeres: cylindrical (0) (Figure 7); binodal (1) (Figure 8); squarish (2) (Figure 9)

6. Shape of circumfila: not anastomosing (0) (Figure 8); anastomosing (1) (Figure 7)
7. Relative length of neck flagellomere (flagellomere total length/neck length): short (from 3.2 to 4.0 ) (0); medium (from 6.20-6.25) (1); long (from 7.5-8.0) (2)

8. Male circumfila shape: X-like (0) (Figure 9); sinuous (2) (Figure 7); reticulated (3) (Figure 10)

9. Relative gonostylus length (gonostylus length/gonostylus width): long (from 4.3 to 6.6) (0) (Figure 11); short (from 1.0 to 3.0) (1) (Figure 12)

10. Shape of short gonostylus: triangular (0) (Figure 13); rectangular (1) (Figure 14); elongate (2) (Figure 15); spherical (3) (Figure 16)

11. Shape of long gonostylus: claviform (0) (Figure 17); cylindrical (1) (Figure 18)

12. Number of gonostylus teeth: 01 (0) (Figure 18); 02 (1) (Figure 16); multiple (2) (Figures 13-15)

13. Relative length of male cerci: longer than large (0) (Figure 11); as long as large (basal width) (1) (Figure 12); larger than long (2) (Figure 19)

14. Parameres: present (0) (Figure 19); absent (1) (Figure 12)

15. Parameres (when present): free (0) (Figure 20); involving aedeagus (1) (Figure 21)

16. Relative length of parameres: appreciably shorter than aedeagus (0) (Figure 22); slightly shorter than aedeagus (1) (Figure 21)

17. Aedeagus shape: triangular (0) (Figure 11); glossiform (1) (Figure 19)

\subsubsection{Female characters}

18. Bilobed structure at the posterior end of $8^{\text {th }}$ tergite: absent (0) (Figure 23); present (1) (Figure 24)

19. Ovipositor relative length: shorter than abdome (0) (Figure 23); longer than abdome (1) (Figures 24 and 25)

20. Texture of ovipositor: soft (0) (Figures 23 and 25); rigid (1) (Figure 24)

21. Modified scales of ovipositor: absent (0) (Figures 23 and 24); present (1) (Figure 25)

22. Cerci: not fused (0) (Figure 26); fused (1) (Figure 27)

23. Degree of fusion of female cerci: completely fused

(0) (Figure 27); partially fused (1) (Figure 23)

24. Closeness of female cerci (when not fused): separate (0) (Figure 26); adjacent (1) (Figure 28)

\subsubsection{Pupa characters}

25. Length of apical seta: very short (until $0.08 \mathrm{~mm})(0)$ (Figure 29); short (from 0.12 to $0.13 \mathrm{~mm}$ ) (1) (Figure 30); long (more than $0.16 \mathrm{~mm}$ ) (2) (Figure 31)

26. Antennal bases: short (until 0.02mm) (0) (Figure 31); long (from 0.30-0.05mm) (1) (Figure 32)

27. Number of lateral facial papillae: 03 (0) (Figure 32); 01 (1) (Figures 30 and 31); 0 (2) (Figure 29)

28. Number of lower facial papillae: 02 (0) (Figures 31 and 32); 01 (1); 0 (3) (Figure 29)

29. Length of prothoracic spiracle: short (until $0.17 \mathrm{~mm}$ ) (0) (Figure 33); medium (from 0.21-0.22mm) (1) (Figure 34); long (more than $0.29 \mathrm{~mm}$ ) (2) (Figure 35)

30. Abdominal dorsal spines: present (0) (Figure 36); absent (1) 


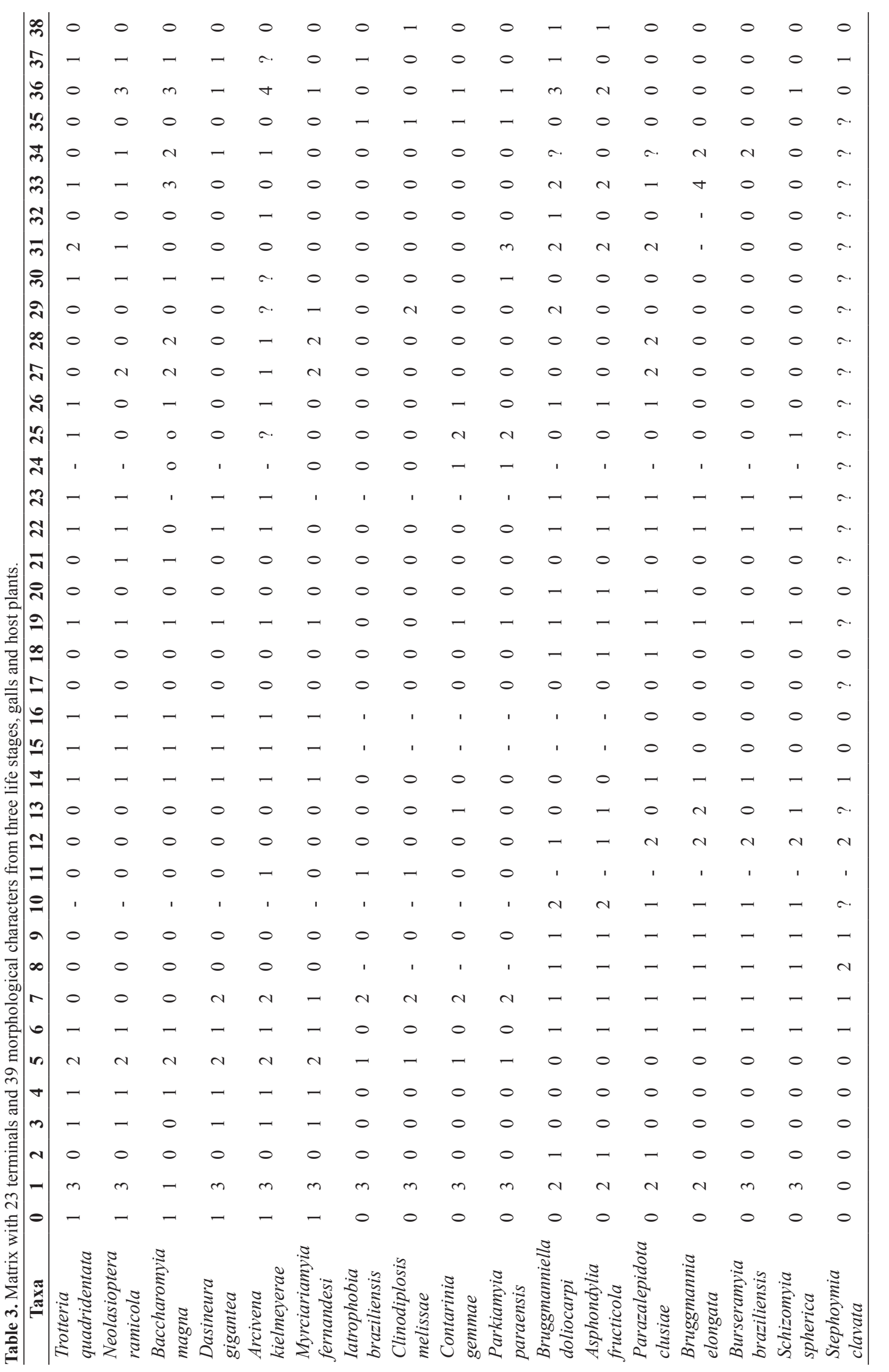


Maia, V.C. and Barbosa, L.S.

$$
\begin{aligned}
& \mid \begin{array}{l|cccccc}
\infty & 0 & 0 & - & 0 & 0 & 0 \\
\tilde{m} & - & - & - & - & - & - \\
0 & 0 & 0 & 0 & 0 & 0 & 0
\end{array}
\end{aligned}
$$

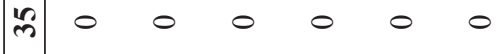

$$
\begin{aligned}
& \text { m N N a. n N N }
\end{aligned}
$$

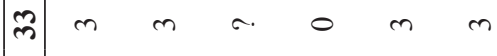

$$
\begin{aligned}
& \text { ल } 0-a \cdot 0-0 \\
& \bar{m} 00 \cdots \text { a }
\end{aligned}
$$

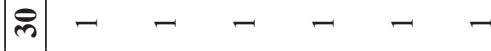

$$
\begin{aligned}
& \text { बे } 0 \text { ० } \\
& \underset{4}{4} \mathrm{n}-a \cdot \mathrm{c}- \\
& \text { ก } N a \text { a n } h-n \\
& \text { N } 0000000 \\
& \begin{array}{lllllll}
4 & 0 & 0 & a & 0 & 0 & 0
\end{array}
\end{aligned}
$$

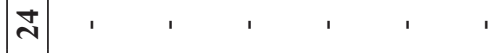

$$
\begin{aligned}
& \approx 00000 \\
& \text { ส }-7-7-7-
\end{aligned}
$$

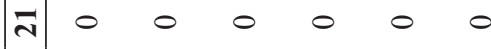

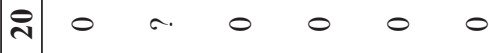

$$
\begin{aligned}
& =00000 \\
& \infty \quad 0 \quad r . \quad 0 \quad 000 \\
& \begin{array}{lllllll} 
\pm & 0 & a & 0 & - & - & - \\
0 & \sigma & 0 & 0 & 0 & 0
\end{array} \\
& \because 0 \text { a } 0 \text { o } 0 \\
& \text { J }-a---
\end{aligned}
$$

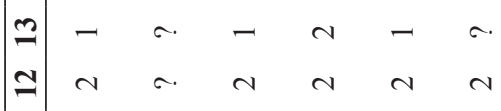

$$
\begin{aligned}
& =1,1,1, \\
& =\mid \begin{array}{llllll}
1 & \cdots & \cdots & 0 & 0 & -
\end{array} \\
& \begin{array}{lllllll}
\infty & 4 & a & 4 & 4 & 2 & 0
\end{array}
\end{aligned}
$$

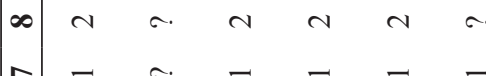

$$
\begin{aligned}
& \begin{array}{lllllll}
- & \sigma & - & - & - & - \\
- & \sigma & - & - & - & -
\end{array} \\
& \text { n } 0 \text { a. o } 0 \text { o } \\
& +00000 \\
& m 000000
\end{aligned}
$$

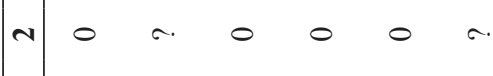

$$
\begin{aligned}
& \begin{array}{lllllll}
- & 0 & 0 & 0 & - & 0 & 0 \\
0 & 0 & 0 & 0 & 0 & 0
\end{array}
\end{aligned}
$$

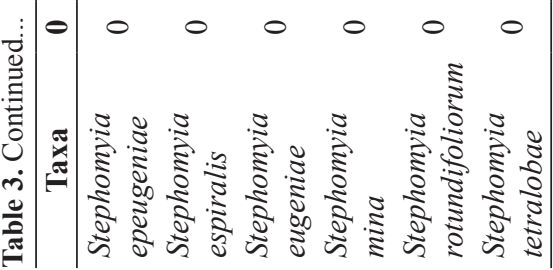




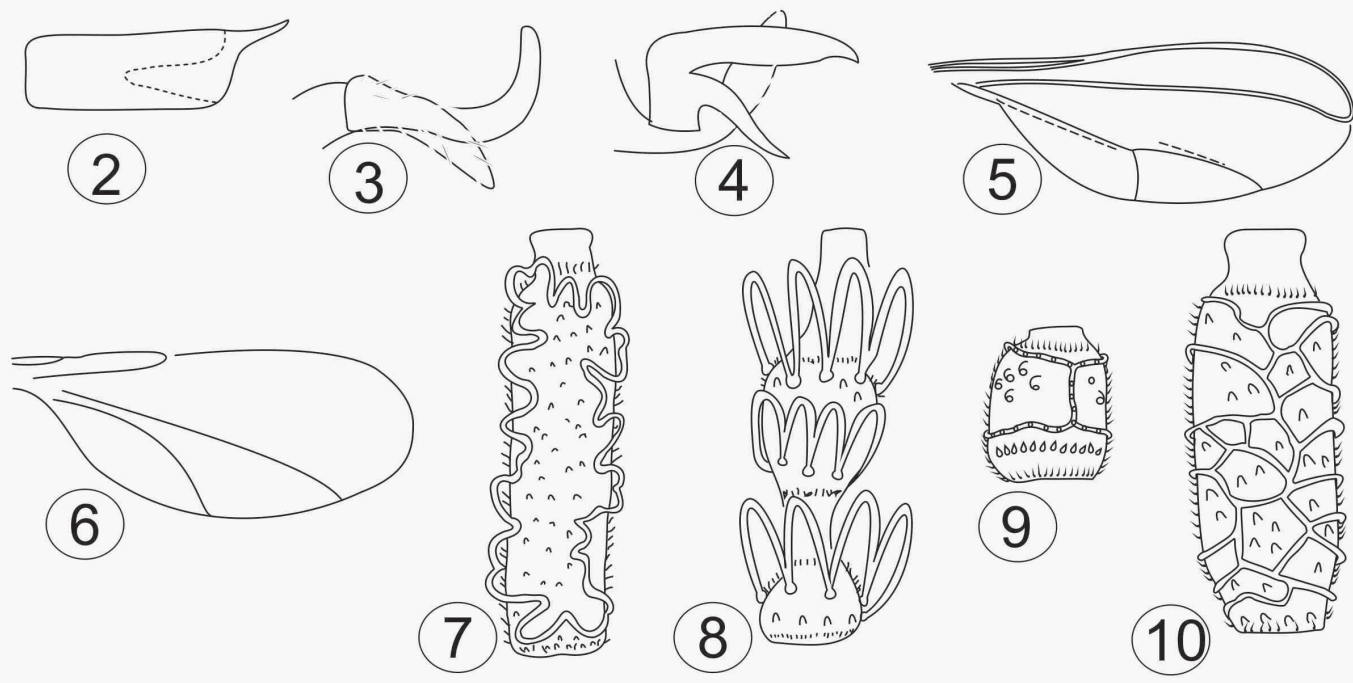

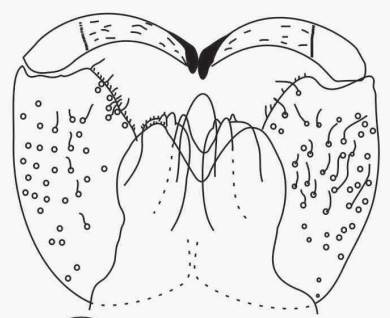

(11)
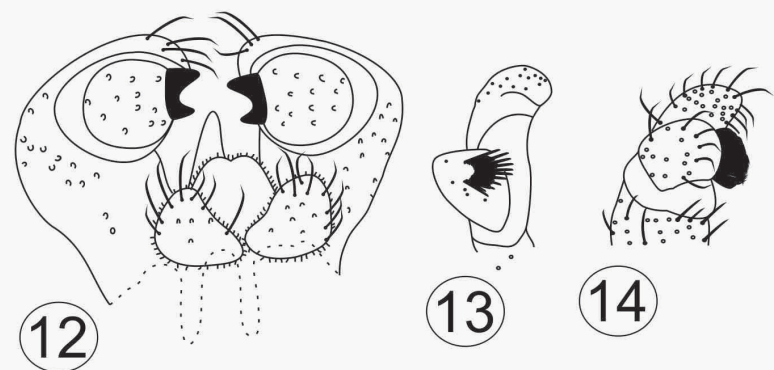

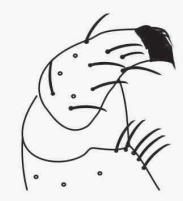

(15)

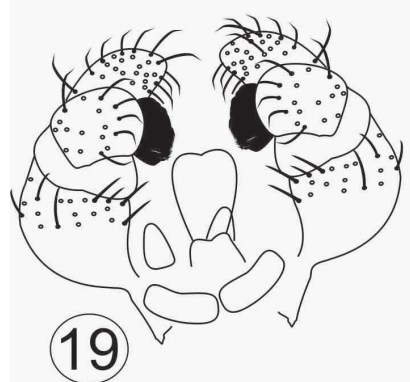

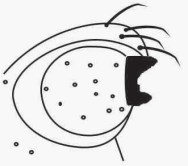

16

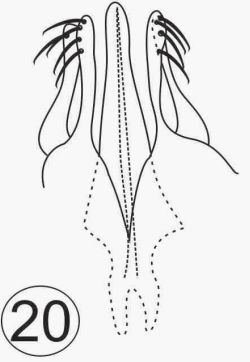

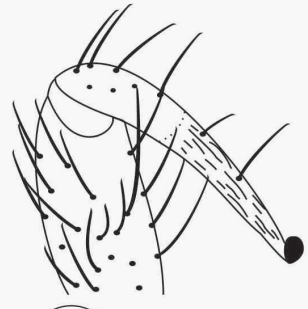

(17)

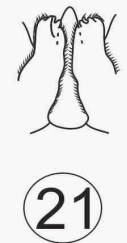

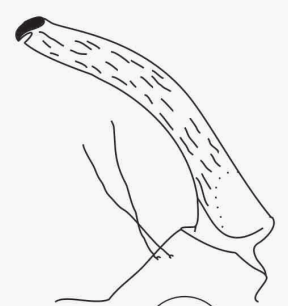

(18)

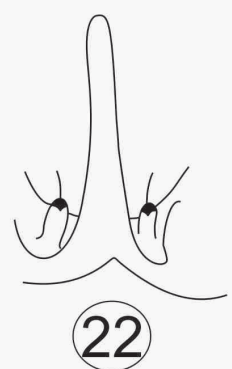

Figures 2-22. Cecidomyiidae (adults): 2) First tarsomere with apical spine; 3) Tarsal claw simple (without teeth); 4) Tarsal claw toothed; 5) Wing: $\mathrm{R}_{5}$ long, reaching $\mathrm{C}$ near the apex; 6) $\mathrm{R}_{5}$ short, reaching $\mathrm{C}$ appreciably before the apex; 7-9): Male antenna, flagellomere: 7) Cylindrical with sinuous circumfila; 8) Binodal with looped circumfila; 9) Squarish with x-shaped circumfila; 10) Antenna, flagellomere cylindrical with reticulated circumfila; 11-23): Male terminalia: 11) Gonostylus narrow, cercus longer than large, parameres absent; 12) Gonostylus broad, cercus as long as large; 13) Gonostylus broad, triangular; 14) Gonostylus broad, rectangular; 15) Gonostylus broad, elongate; 16) Gonostylus broad, spherical, with two teeth; 17) Gonostylus narrow, claviform, with a single tooth; 18) Gonostylus narrow, cylindrical, with a single tooth; 19) Gonostylus broad, rectangular with multiple teeth, cercus larger than long, parameres present, aedeagus glossiform; 20-22) Parameres: 20) Free, sligthly shorter than aedeagus; 21) Envolving aedeagus; 22) Appreciably shorter than aedeagus. 

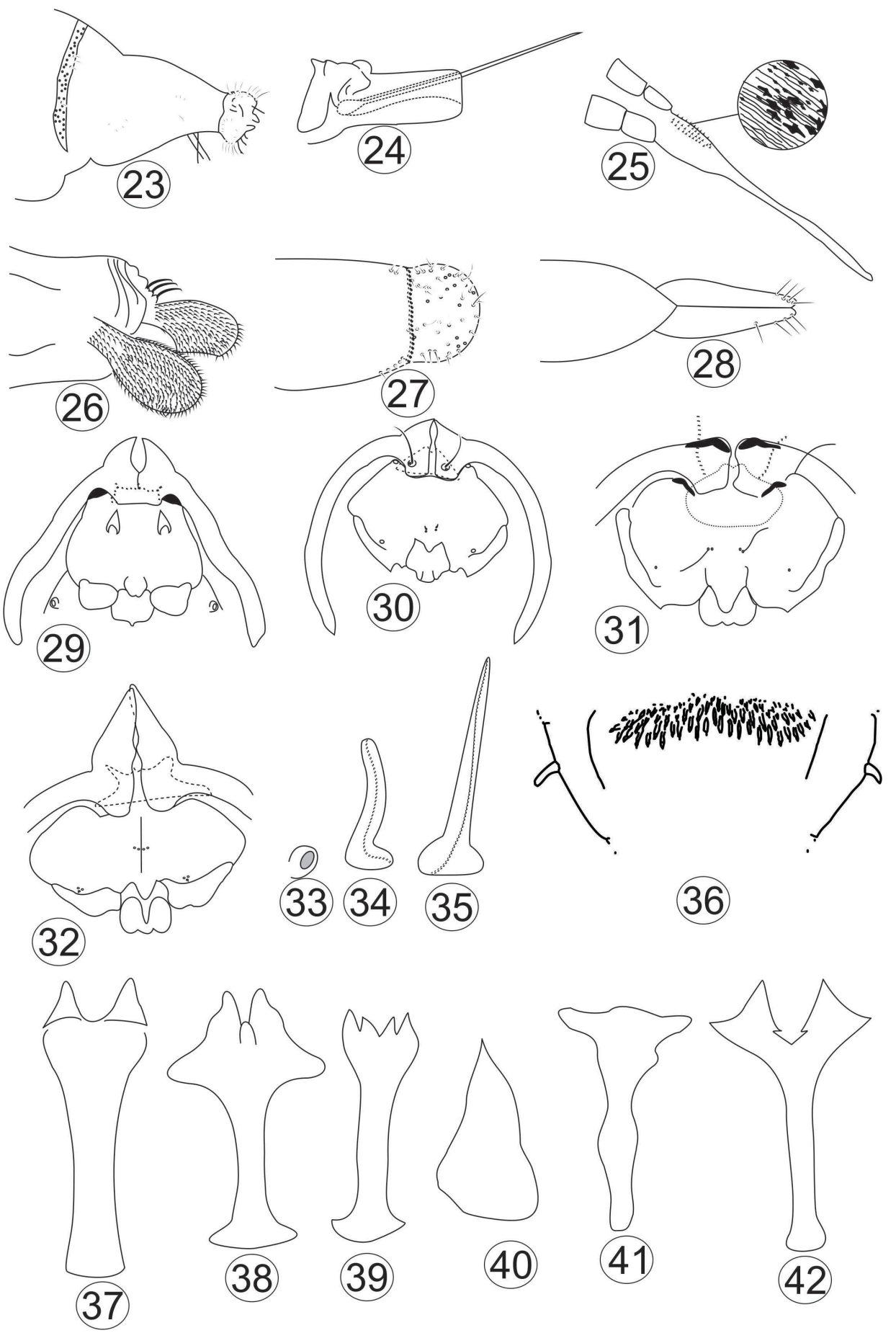

Figures 23-42. Cecidomyiidae (females and immature phases): 23-24) Female terminalia 23) $8^{\text {th }}$ tergite without a bilobed structure at the posterior end, ovipositor soft, shorter than abdome, without modified scales, cerci partially fused; 24) $8^{\text {th }}$ tergite with a bilobed structure at the posterior end, ovipositor rigid, longer than abdome, without modified scales; 25) Ovipositor soft, longer than abdome, with modified scales; 26-28) Female cerci: 26) Not fused with lobes separate; 27) Fused (completely); 28) Not fused with adjacent lobes; 29-32) Pupa, head: 29) Apical seta very short, lateral papillae and lower facial absent; 30) Apical seta short, two pairs of facial papillae (one lateral and other lower); 31) Apical seta long, antennal basesshort, a single pair of lateral papillae and two pairs of lower facial papillae; 32) Antennal bases long, three pairs of lateral papillae and two pairs of lower facial papillae; 33-35) Pupa, prothoracic spiracle: 33) Short; 34) Medium; 35) Long; 36) Pupa, dorsal abdominal spines; 37-42) Larva, prothoracic spatula: 37) With two teeth; 38) With three teeth; 39) With four teeth; 40) With a single tooth; 41) Without medial broadening; 42) With medial broadening. 


\subsubsection{Larva characters}

31. Number of apical teeth of the prothoracic spatula: 02 (0) (Figure 37); 03 (1) (Figure 38); 04 (2) (Figure 39); 01 (3) (Figure 40)

32. Medial broadening of spatula: absent (0) (Figure 41); present (1) (Figures 38 and 42)

33. Number of lateral papillae (on each side of the spatula): 06 (0) (Figure 43); 04 (1) (Figure 44); 03 (2) (Figure 45); 02 (3) (Figure 46); 0 (4)

34. Number of terminal papillae: 04 pairs (0) (Figure 47); 03 pairs (1) (Figure 48); 02 pairs (2)

35. Stubby terminal papillae: absent (0) (Figure 47); present (1) (Figure 48)

\subsubsection{Gall characters}

36. Galled plant organ: leaf (0) (Figure 49); bud (1) (Figure 50); fruit (2) (Figure 51); stem (3) (Figure 52); flower bud (4) (Figure 53)

37. Relative length: as long as large (0) (Figure 49); longer than large (1) (Figure 54)

38. Indumentary: glabrous (0) (Figure 54); with trichomes (1) (Figure 49)

\section{Results and Discussion}

Both analyses obtained the same result, two cladograms, with 105 steps, consistency index 57 and retention index 76 (Figure 55A and B). The strict consensus arising from this result showed 106 steps, consistency index 56 and retention index 76 (Figure 55C).

Stephomyia is a monophyletic genus, supported by eight synapomorphies, five homoplastic: ovipositor shorter than abdomen (19), none lateral facial papillae
(27), abdominal dorsal spines absent (30), gall longer than large (37); and three non-homoplastic: male circumfila sinuous (8), gonostylus short and triangular (10), female cerci: completely fused (23).

Stephomyia mina is the basal clade of genus, all remain species are grouped by two homoplastic synapomorphies: male cerci as long as large (13) and two lateral papillae on each side of the spatula (33). This clade is divided into two others: (S. eugeniae + S. epeugeniae) and (S. tetralobae $(S$. rotundifoliorum + S. espiralis $))$, the last one is grouped by one synapomorphy: only one lower facial papilla (28).

The clade (S. rotundifoliorum $+S$. espiralis) has one synapomorphy: presence of medial broadening of spatula (32). S. eugeniae shows an exclusive apomorphy, gall indumentary with trichomes (38), not shared with others Stephomyia.

The cladogram shows that the basal host plant is Neomitranthes obscura (S. mina). The other species occurs only in Eugenia, as a monophyletic clade. (Figure 56). S. epeugeniae occurs in an undetermined Eugenia species and the host of $S$. clavata is identified in family level, Myrtaceae (Table 1$)$. The clade ( $S$. tetralobae $(S$. rotundifoliorum, $S$. espiralis) is associated with two endemic plant species of Atlantic Forest: E. astringens and E. copacabanensis.

Considering the species geographic distribution and the position of the only one Neartic terminal taxon, S. eugeniae, we suggest a South America origin for Stephomyia with a posterior colonization of North America (Figure 57). This is the first cladistic approach of a Neotropical genus of Cecidomyiidae.
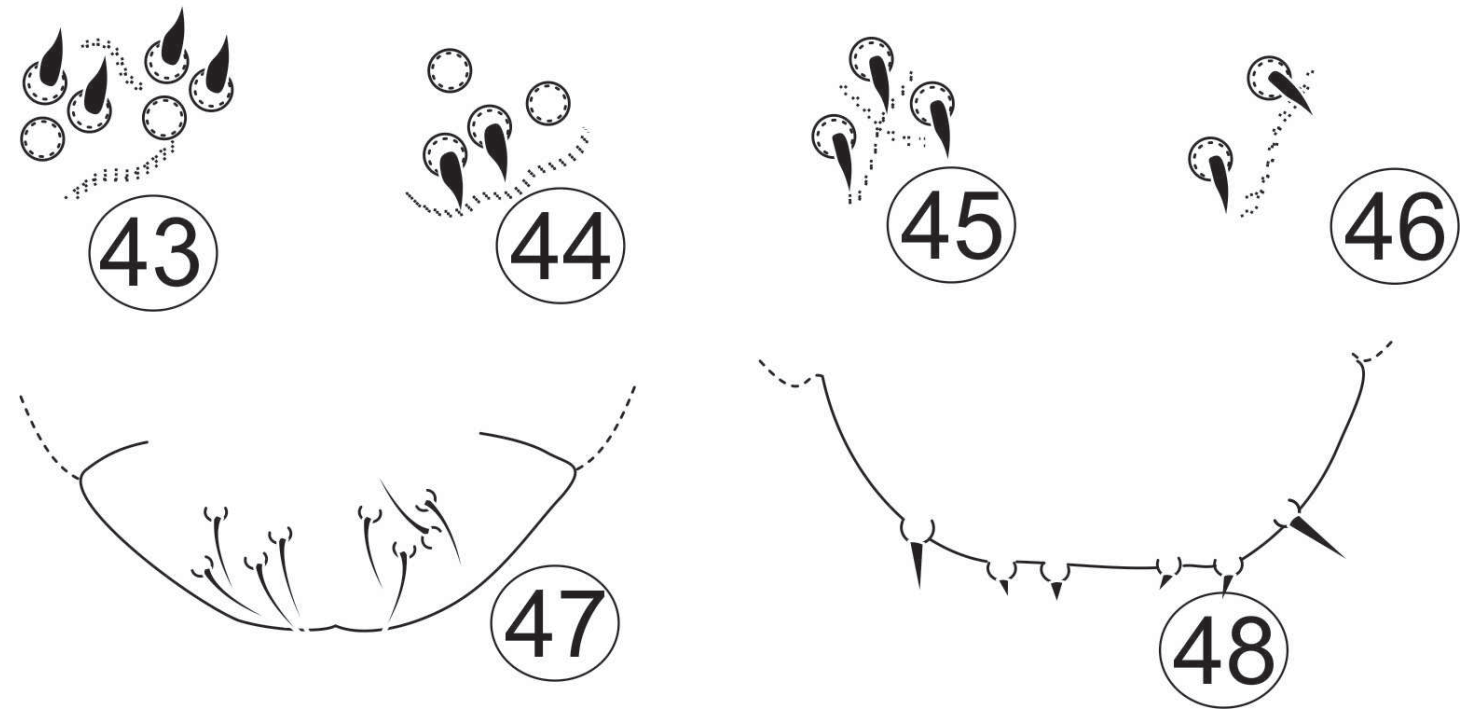

Figures 43-48. Larva, number of lateral papillae: 43) Six pairs; 44) Four pairs; 45) Three pairs; 46) Two pairs; 47-48) Larva, last abdominal segment: 47) Four pairs of terminal papillae, stubby papillae absent; 48) Three pairs of terminal papillae, stubby papillae present. 


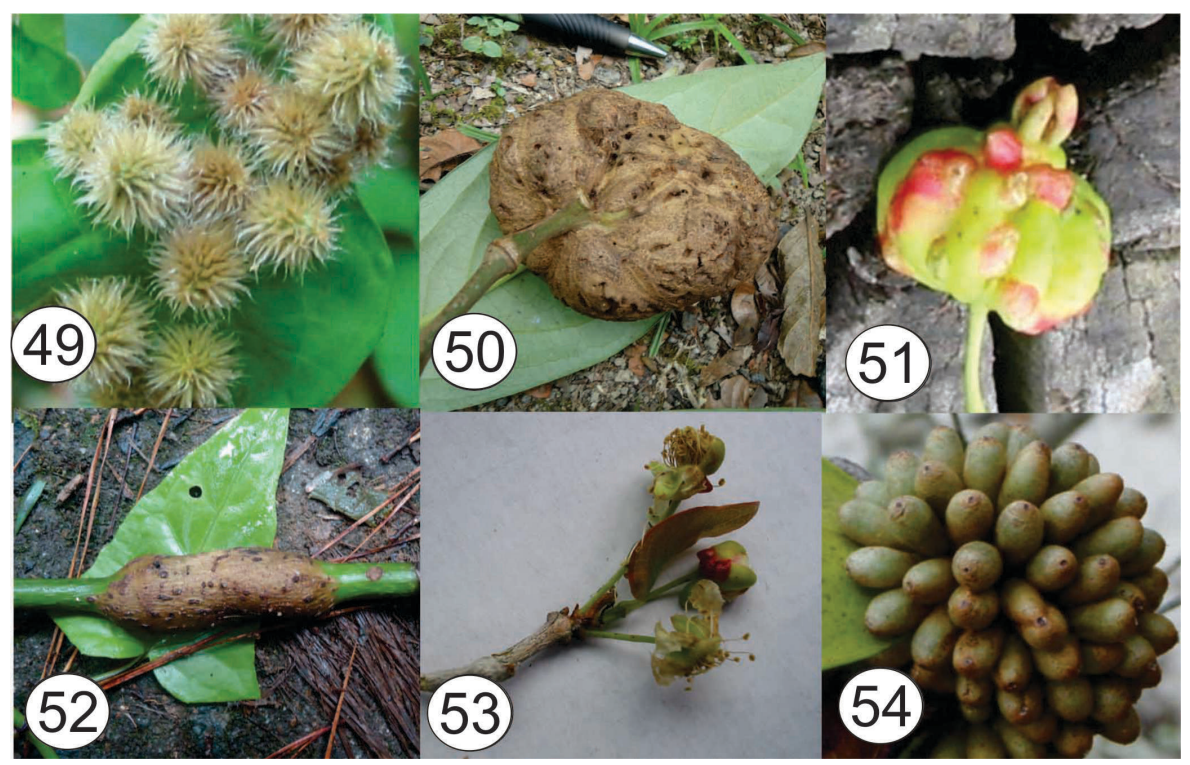

Figures 49-54. 49) Leaf gall, as long as large, with trichomes; 50) Bud gall, glabrous; 51) Fruit gall, glabrous; 52) Stem gall, glabrous; 53) Flower bud gall, glabrous; 54) Bud gall, longer than large, glabrous.
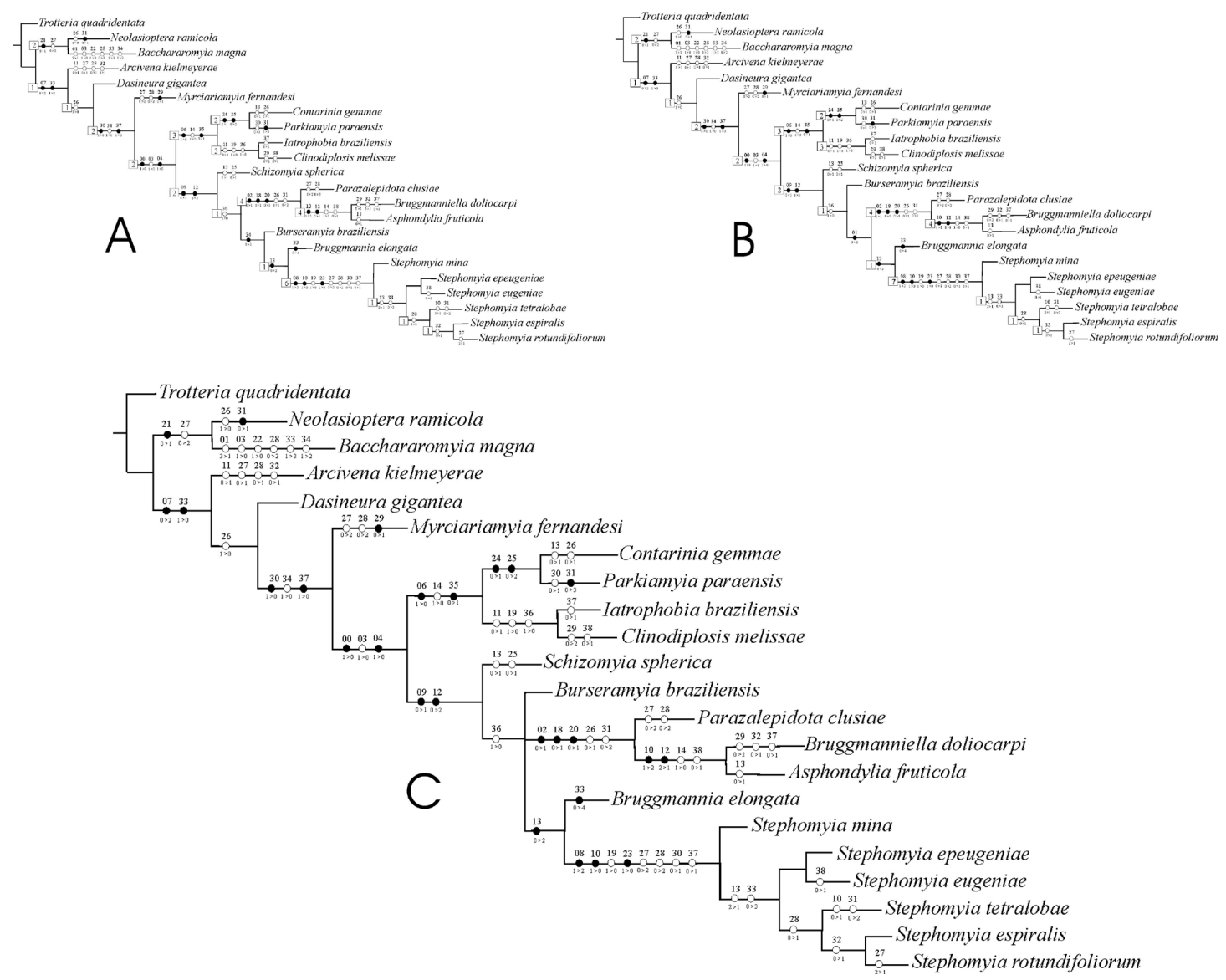

Figure 55. (A) and (B) Most parsimonious cladograms obtained (105 steps, ci 57, ri 76), (C) Strict consensus cladograms obtained (106 steps, ci 56, ri 76). The number inside the box refers to the Bremer value. 

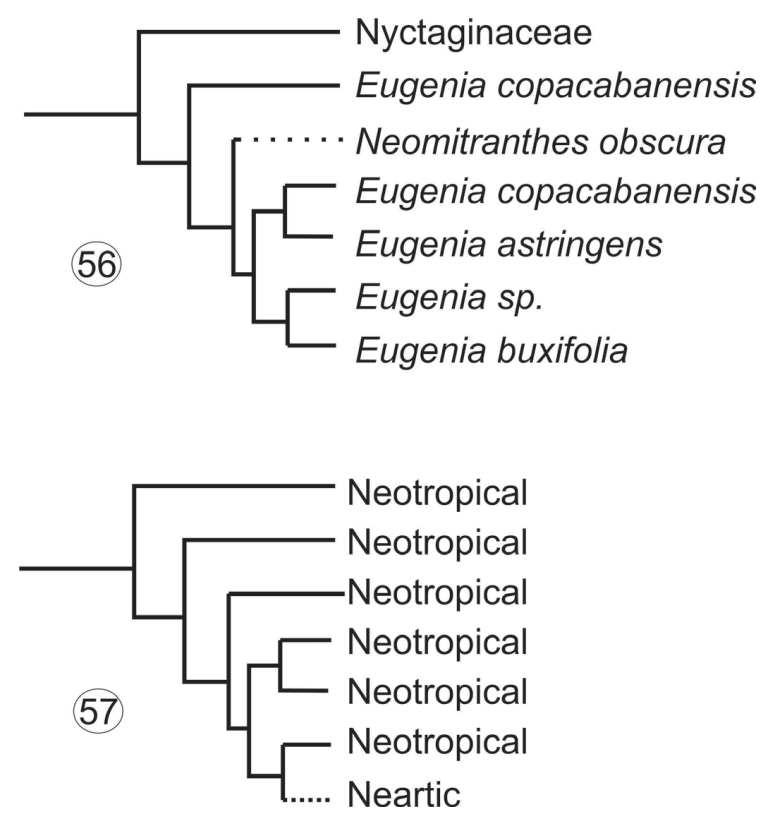

Figures 56-57. 56) Interpolating cladogram of the Stephomyia species with terminal taxa replaced by their respective host plants; 57) Interpolating cladogram of the Stephomyia species with terminal taxa replaced by their area of occurrence.

\section{Conclusions}

Stephomyia is a monophyletic genus. S. mina is the sister group of the remainders two groups: (S. eugeniae, $S$. epeugeniae) and $(S$. tetralobae $(S$. rotundifoliorum, $S$. espiralis) The genus origin is probably in South America with secondary incursion into North America. The basal host plant is Neomitranthes obscura. For greater refinement, more data on $S$. clavata should be known to locate its relationship with the others Stephomyia.

\section{Acknowledgements}

To CNPq and FAPERJ/CAPES by financial support (VCM Proc. 371848/2013-0), LSB Proc. E-26/100.072/2013).

\section{References}

ANGELO, A.C. and MAIA, V.C., 1999. Dasineura gigantea sp.n. (Diptera, Cecidomyiidae) associada a Psidium cattleianum Sabine (Myrtaceae) no Brasil. Revista Brasileira de Zoologia, vol. 16, no. 1, pp. 191-195. http://dx.doi.org/10.1590/S010181751999000100014 .

BREMER, K., 1994. Branch support and tree stability. Cladistics, vol. 10, no. 3, pp. 295-304. http://dx.doi.org/10.1111/j.1096-0031.1994. tb00179.x.

DORCHIN, N., JOY, J.B., HILKE, L.K., WISE, M.J. and ABRAHAMSON, W.G., 2015. Taxonomy and phylogeny of the Asphondylia species (Diptera: Cecidomyiidae) of North American goldenrods: Challenging morphology, complex host associations, and cryptic speciation. Zoological Journal of the Linnean Society, vol. 174, no. 2, pp. 265-304. http://dx.doi.org/10.1111/zoj.12234.

FELT, E.P., 1913. Cystodiplosis eugeniae n. sp. (Dipt.). Entomological News, vol. 24, pp. 175-176.
GAGNÉ, R.J. and JASCHHOF, M., 2014 [viewed 10 April 2016]. A Catalog of the Cecidomyiidae (Diptera) of the World [online]. 3rd ed. Available from: https://www.ars.usda.gov/ARSUserFiles/80420580/ Gagne_2014_World_Cecidomyiidae_Catalog_3rd_Edition.pdf

GAGNÉ, R.J., 1984. Five new species of Neotropical Cecidomyiidae (Diptera) associated with cacao flowers, killing the buds of Clusiaceae, or preying on mites. Brenesia, vol. 22, pp. 123-138.

GAGNÉ, R.J., 1994. The gall midges of the Neotropical region. Ithaca: Comstock Cornell University Press. 352 p.

GOLOBOFF, P., FARRIS, J. and NIXON, K., 2005. TNT: Tree analysis using New Technology. Systematic Biology, vol. 54, no. 1 , pp. 176-178.

MADEIRA, J.A., MAIA, V.C. and MONTEIRO, R.F., 2002. Gall markers (Cecidomyiidae, Diptera) on Calophyllum brasiliense Camb. (Clusiaceae): descriptions and biology. Arquivos do Museu Nacional, vol. 61, no. 1, pp. 31-48.

MAIA, V.C. and CARNEIRO, M.A.A., 2012. A new species of Baccharomyia (Diptera, Cecidomyiidae) from Baccharis pseudomiryocephala (Asteraceae) in Brazil. Vestnik Zoologii, vol. 46, no. 2, pp. 23-28. http://dx.doi.org/10.2478/v10058-012-0012-2.

MAIA, V.C. and COURI, M.S., 1993. Descrição de três espécies novas de Bruggmannia Tavares, 1906 (Diptera, Cecidomyiidae, Asphondyliidi) do Brasil associadas com Guapira opposita (Nyctaginaceae). Revista Brasileira de Biologia, vol. 53, no. 2, pp. 209-215.

MAIA, V.C. and FERNANDES, G.W., 2006. A new genus and species of gall midge (Diptera, Cecidomyiidae) associated with Parkia pendula (Fabaceae, Mimosoideae). Revista Brasileira de Entomologia, vol. 50, no. 1, pp. 1-15. http://dx.doi.org/10.1590/ S0085-56262006000100001.

MAIA, V.C. and FONSECA, K.F., 2012. Burseramyia braziliensis, a new species of gall midge (Diptera, Cecidomyiidae, Asphondyliini) 
associated with Swartzia langsdorffii Raddi (Fabaceae). Biota Neotropica, vol. 4, pp. 55-57.

MAIA, V.C. and OLIVEIRA, U.P., 2007. Uma nova espécie de Cecidomyiidae (Diptera) associada com Sebastiania glandulosa (Euphorbiaceae). Iheringia, vol. 97, no. 1, pp. 97-101. http:// dx.doi.org/10.1590/S0073-47212007000100014.

MAIA, V.C., 1993a. Considerações sobre Stephomyia Tavares (Diptera, Cecidomyiidae, Asphondyliidi), com descrição de quatro espécies novas associadas com Eugenia L. e Neomitranthes obscura (DC.) Legr. (Myrtaceae). Revista Brasileira de Zoologia, vol. 10, no. 3, pp. 521-530. http://dx.doi.org/10.1590/S010181751993000300019 .

MAIA, V.C., 1993b. Uma nova espécie de Clinodiplosis Kieffer (Diptera, Cecidomyiidae) associada com Melissa officinalis Linnaeus (Labiatae) no Brasil. Revista Brasileira de Zoologia, vol. 10 , no. 4 , pp. 695-697. http://dx.doi.org/10.1590/S010181751993000400014 .

MAIA, V.C., 2001a. New genera and species of gall midges (Diptera, Cecidomyiidae) from three restingas of Rio de Janeiro State, Brazil. Revista Brasileira de Zoologia, vol. 18, no. 1, suppl. 1, pp. 1-32. http://dx.doi.org/10.1590/S0101-81752001000500001.

MAIA, V.C., 2001b. Two new species od gall midges (Diptera, Cecidomyiidae) assocciated with Pouteria caimito var. laurifolia (Sapotaceae) in Brazil. Studia Dipterologica, vol. 8, no. 1, pp. 103-110.

MAIA, V.C., 2002. Description of the male of Stephomyia tetralobae Maia, 1993 (Diptera, Cecidomyiidae). Boletim do Museu Nacional, vol. 479, pp. 1-13.

MAIA, V.C., 2004. A new genus and six new species of gall midges (Diptera, Cecidomyiidae) from Serra de São José (Minas Gerais State, Brazil). Arquivos do Museu Nacional, vol. 62, pp. 69-82.

MAIA, V.C., FERNANDES, G.W. and OLIVEIRA, L.A., 2010. A new species of Bruggmanniella (Diptera, Cecidomyiidae, Asphondyliini) associated with Doliocarpus dentatus (Dilleniaceae) in Brazil. Revista Brasileira de Entomologia, vol. 54, no. 2, pp. 225-228. http://dx.doi.org/10.1590/S0085-56262010000200004.

MAIA, V.C., SANTOS, J.C. and FERNANDES, G.W., 2009a. Asphondylia fructicola, a new species of Cecidomyiidae (Diptera) associated with Solanum sp. (Solanaceae) from Brazil. Revista Brasileira de Entomologia, vol. 53, no. 2, pp. 166-170. http:// dx.doi.org/10.1590/S0085-56262009000200002.

MAIA, V.C., ZART, M. and BOTTON, M., 2009b. Neolasioptera ramicola, a new species of Cecidomyiidae (Diptera) associated with Physalis angulata (Solanaceae). Revista Brasileira de Entomologia, vol. 53, no. 2, pp. 163-165. http://dx.doi.org/10.1590/ S0085-56262009000200001.

MCALPINE, J.F., 1981. Manual of Neartic Diptera. Quebec: Research Branch Agriculture Canada. 674 p.

MÖHN, E., 1962. Studien über neotropische Gallmücken (Diptera, Itonididae). 1. Teil. Brotéria, vol. 31, pp. 211-239.

NIXON, K.C., 1999 [viewed 10 April 2016]. Winclada (beta) ver. 0.9 [online]. Ithaca. Available from: http://www.cladistics.com

RÜBSAAMEN, E.H., 1907. Beiträge zur Kenntnis aussereuropäischer Zoocecidien. III. [cont.]: Gallen aus Brasilien und Peru. Marcellia. Avellino, vol. 6, pp. 110-173.

RÜBSAAMEN, E.H., 1916. Beiträge zur Kenntnis aussereuropäischer Gallmücker. Sitzungsberichte der Gesellshaft Naturforschender Freunde zu Berlin, vol. 1915, pp. 431-485.

TAVARES, J.S., 1916. Cecidomyias novas do Brazil. p. 36-57. Brotéria Série Zoológica, vol. 14.

TAVARES, J.S., 1920. Cecidologia brazileira: cecídias que se criam em plantas das famílias das Leguminosae, Sapotaceae, Lauraceae, Myrtaceae, Punicaceae, Aurantiaceae, Malpighiaceae, Sapindaceae, Umbelliferae, Loranthaceae, Apocynaceae, Urticaceae, Salicaceae e Gramineae. Brotéria Série Zoológica, vol. 18, no. 2, p. 82-96.

TOKUDA, M., HARRIS, K.M. and YUKAWA, J., 2005. Morphological features and molecular phylogeny of Placochela Rübsaamen (Diptera: Cecidomyiidae) with implications for taxonomy and host specificity. Entomological Science, vol. 8, no. 4, pp. 419-427. http://dx.doi.org/10.1111/j.1479-8298.2005.00141.x.

TOKUDA, M., YANG, M.M. and YUKAWA, J., 2008. Taxonomy and molecular phylogeny of Daphnephila gall midges (Diptera: Cecidomyiidae) inducing complex leaf galls on Lauraceae, with descriptions of five new species associated with Machilus thunbergii in Taiwan. Zoological Science, vol. 25, no. 5, pp. 533-545. PMid:18558807. http://dx.doi.org/10.2108/zsj.25.533. 